\title{
Money Growth Stability and Inflation: An International Comparison
}

\author{
DALLAS S. BATTEN
}

$\mathbf{S}$ procedure in October 1979, the Federal Reserve continuously has been criticized for creating additional instability within financial markets around the world. ${ }^{1}$ Critics point out that this increased instability has been caused by the volatile short-run money growth in the United States, the result of the Fed's attempt to more directly control the money supply by focusing more on the growth of reserves and less on smoothing interest rates. The purpose of this note is to compare briefly the short-run volatility of money growth in the United States, Germany, Switzerland and the United Kingdom and to investigate the longer-run trend of money grow th in these countries over the last two decades. Germany and Switzerland have been chosen because each is usually considered to be a bastion of stable long-run money growth. The United Kingdom is of interest becalse of the "monetarist experiment" that is currently being conducted there. ${ }^{2}$

The pattern of money growth has distinct economic ramifications. ${ }^{3}$ The first impact of a change in the rate of money grow th is felt by the real economy. ${ }^{4}$ In particular, a sustained change in the rate of money growth initially has a positive effect on the level of real output (and, concomitantly, employment) with a lag of two or three quarters. ${ }^{5}$ Unstable money growth

\footnotetext{
'See, for example, Bank for International Settlements, Fifty-First Amual Report (1981), pp. 69-75; and Milton Friedman, "Monetary Instatility," Newsucek June 15, 1981), 13. 80.

The following analysis has also been performed for Comada and Japan. The results are qualitatively similar to those reported for the countries included in this note.

${ }^{3}$ Leonall C. Andersen and Keith M. Carlson, "A Moneturist Model for Ecomomic Stabilization," th is Review (April 1970), pp. $7-25$.

4Financial markets also are initially affected by a change in the rate of money growth. However, the nature of this impact is unclear and beyond the scope of this note.

${ }^{3}$ A sustained change is usually defined as one persisting for at lenst two consecutive quarters.
}

(i.e., frequent directional changes in the rate of money growth) will result in unstable output growth. Consequently, in this tramework, money growth volatility in the short run is undesirable because of the ebbs and flows in employment that it creates. This effect will only be temporary, however, since output growth is closely linked to the rate of growth of productive resources in the long run.

The secondary impact of a sustained change in the rate of money growth is on prices. This impact inj. tially is relatively small because of the buffering effect of the change in output growth. After the output effect has filtered through the economy (i.e., after output growth has returned to its trend level), the rate of price change completely reflects the effect of a sustaned change in the rate of money growth. This reflection is usually accomplished within 12 to 20 quarters. ${ }^{6}$ In other words, while in the short run a change in the rate of money growth primarily affects output growth, in the long run this change in money growth is transmitted entirely to price level growth (i.e., inflation). Consequently, in order to ensure price stability, the policymaker must control money growth so that, in the long rum, the money supply grows at approximately the same rate as the difference between the grow th in velocity and real output.

From the discussion above, then, the performance of monetary authorities must be evaluated from two perspectives: short-run variability and long-run trend. Charts 1 and 2 and tables 1 and 2 summarize the analysis from these two points of view. Specifcally, the panels in chart 1 contain (a) the quarterto-quarter annual rate of money growth, (b) a linear

\footnotetext{
This range for the lag fom a change in the rate of money growth to a change in the rate of infation is supported by Denis $S$. Karnosky, "The Link Between Money and Pricesm 1971-76," this Review (June 1976), pp. 17-23; Keith M. Caxson, "The Latg from Money to Prices," this Reciew (October 1980), pp. 3-10; and John A. Tatom, "Energy Prices and Short-Ran Economic Performance," this Review Uanuary 1981), pp. 3-17.
} 


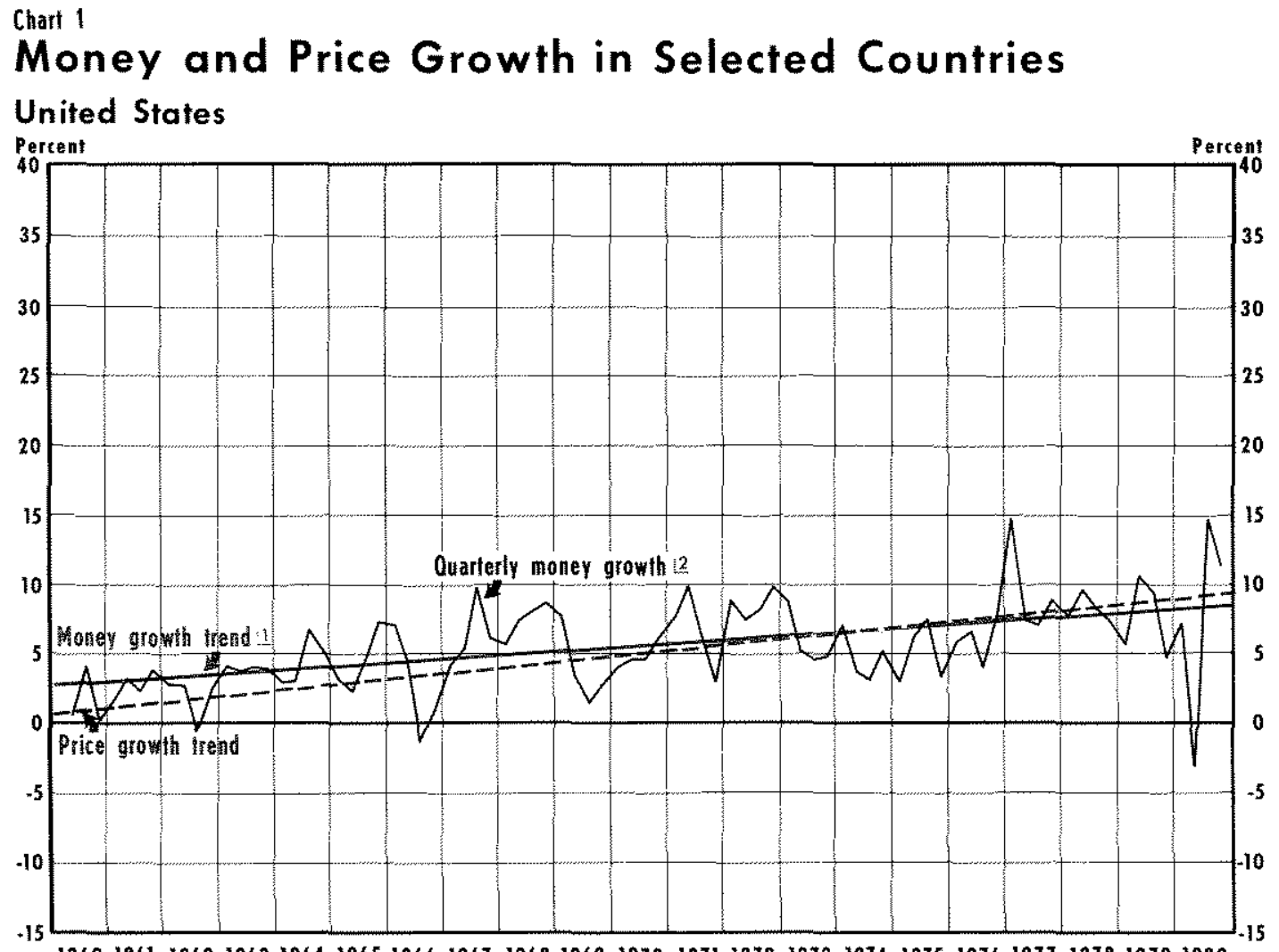

$19601961 \quad 19621963196419651966 \quad 1967 \quad 1968196919701971 \quad 1972 \quad 19731974197519761977197819791980$

\section{United Kingdom}

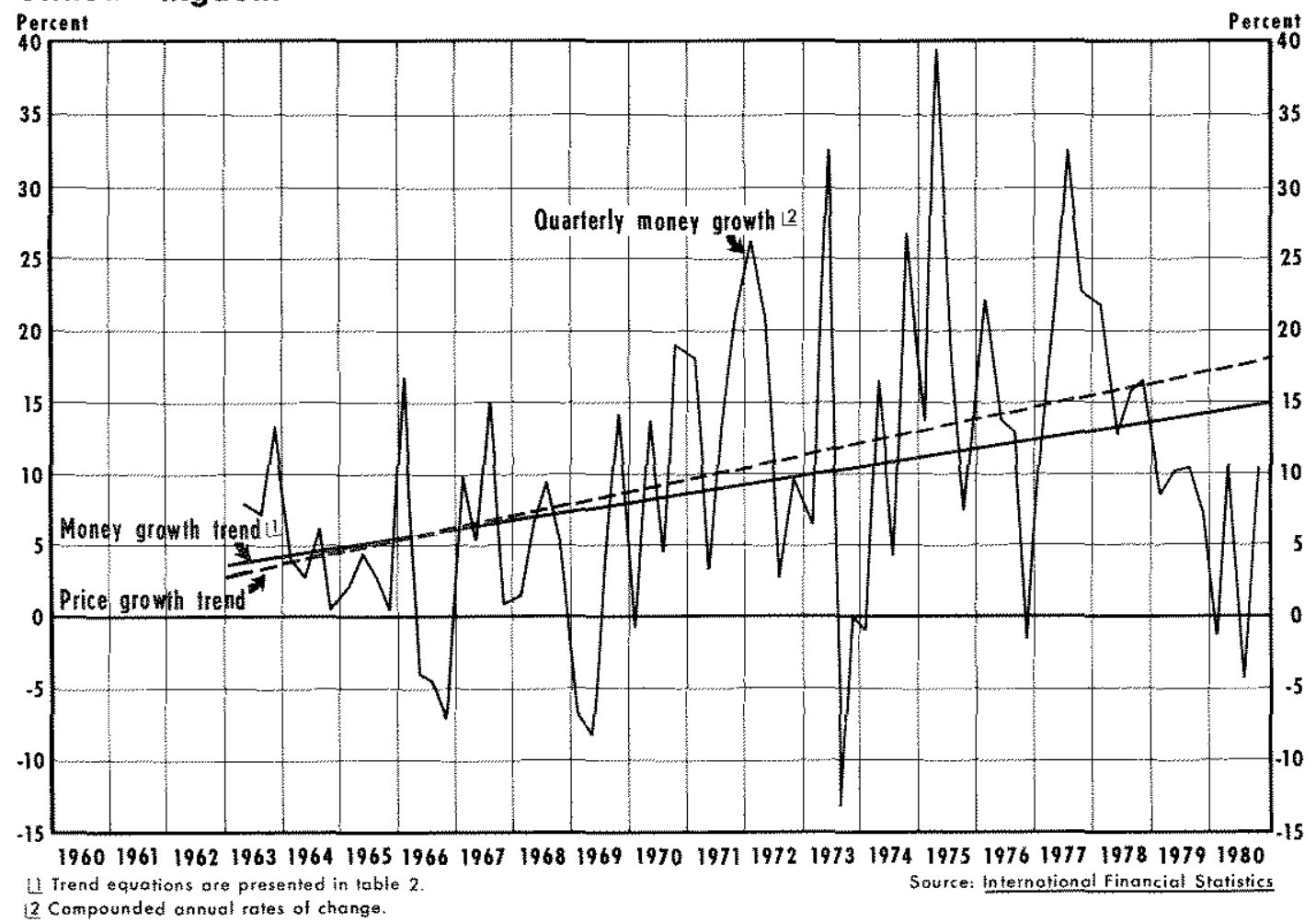




\section{Money and Price Growth in Selected Countries}

\section{Germany}

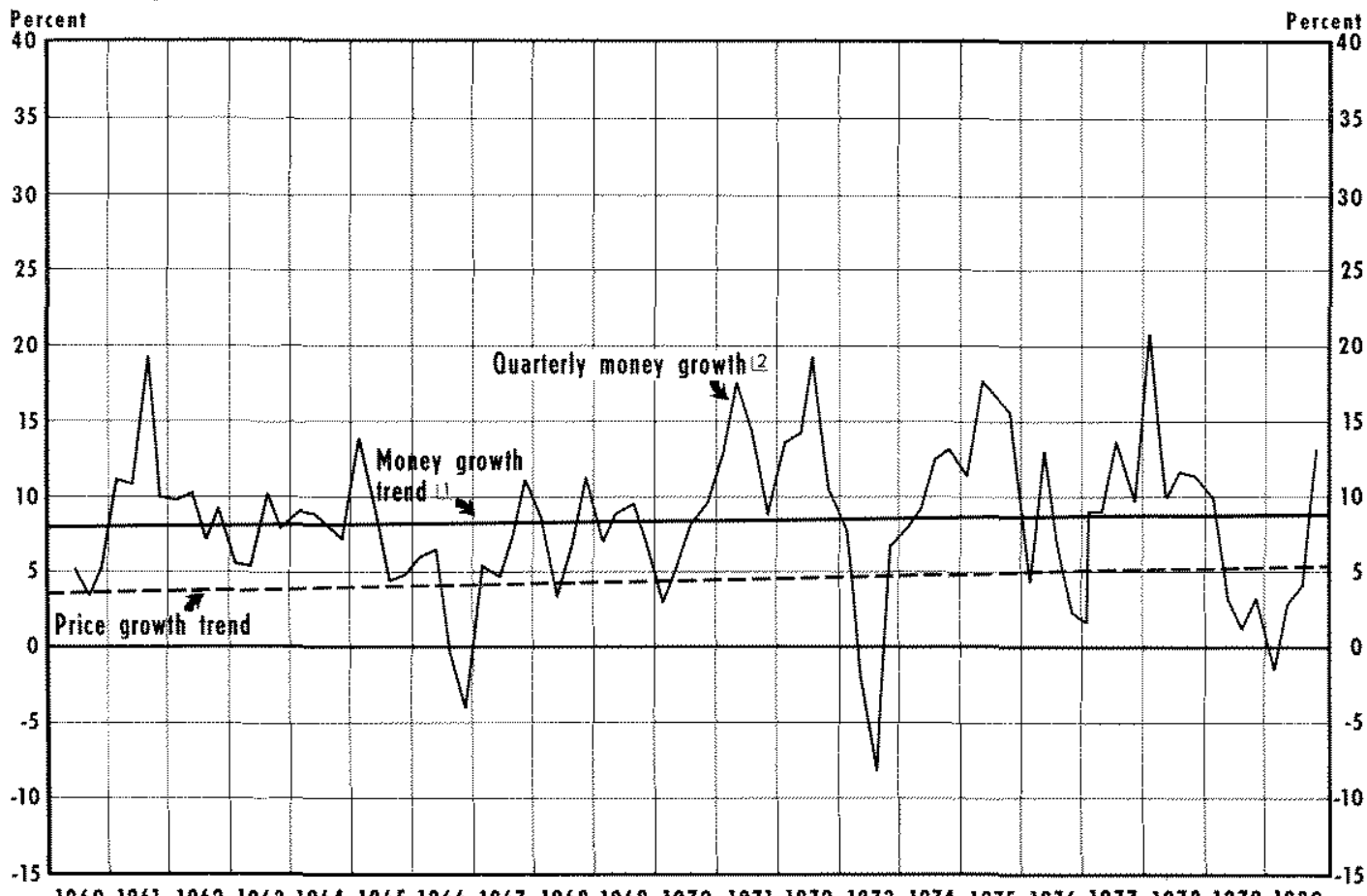

196019611962196319641965196619671968196919701971197219731974197519761977197819791980

\section{Switzerland}

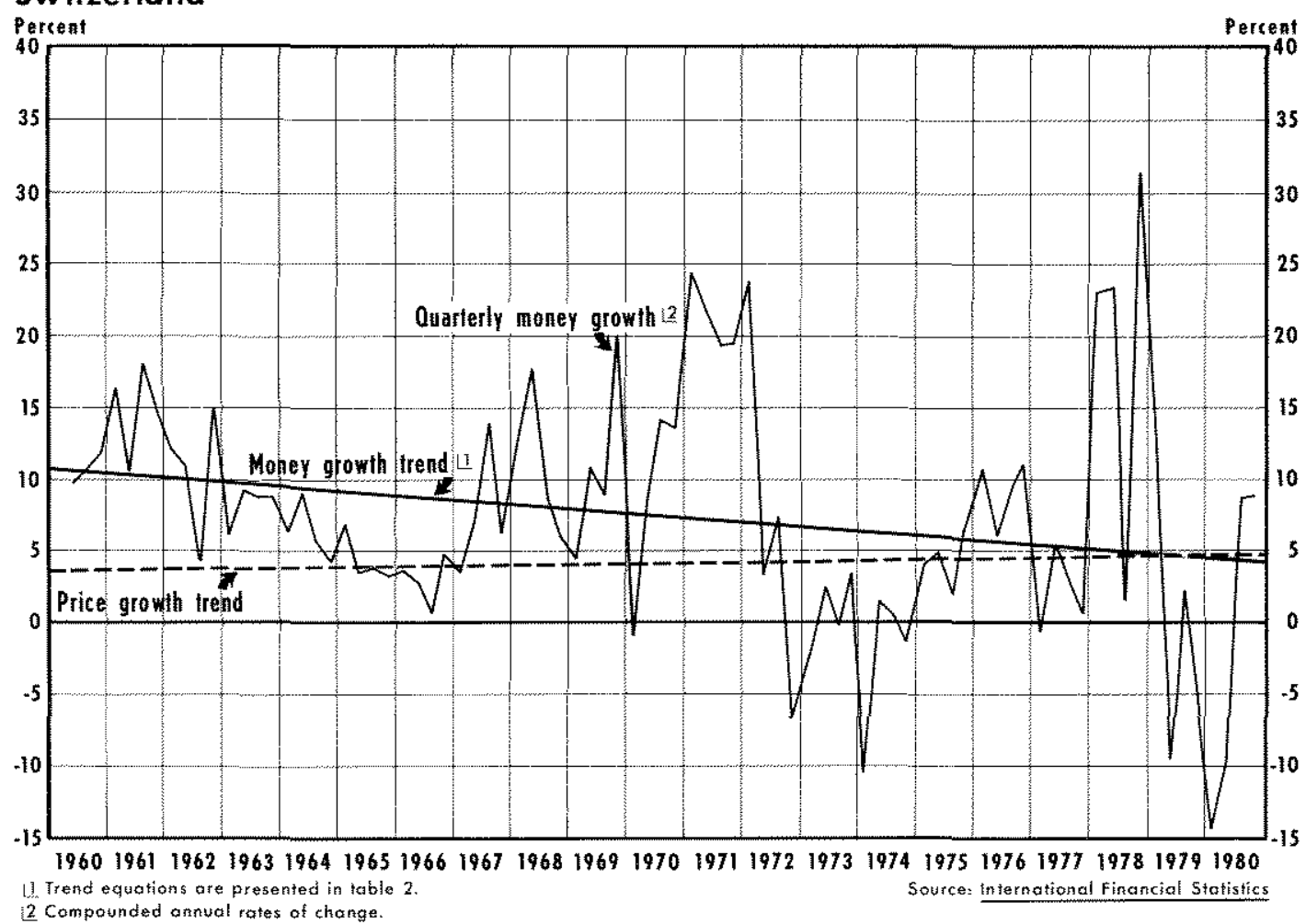

2 Compotunded ormut rates of chorge. 
Chart 2

\section{Long-Term Interest Rates in Selected Countries}

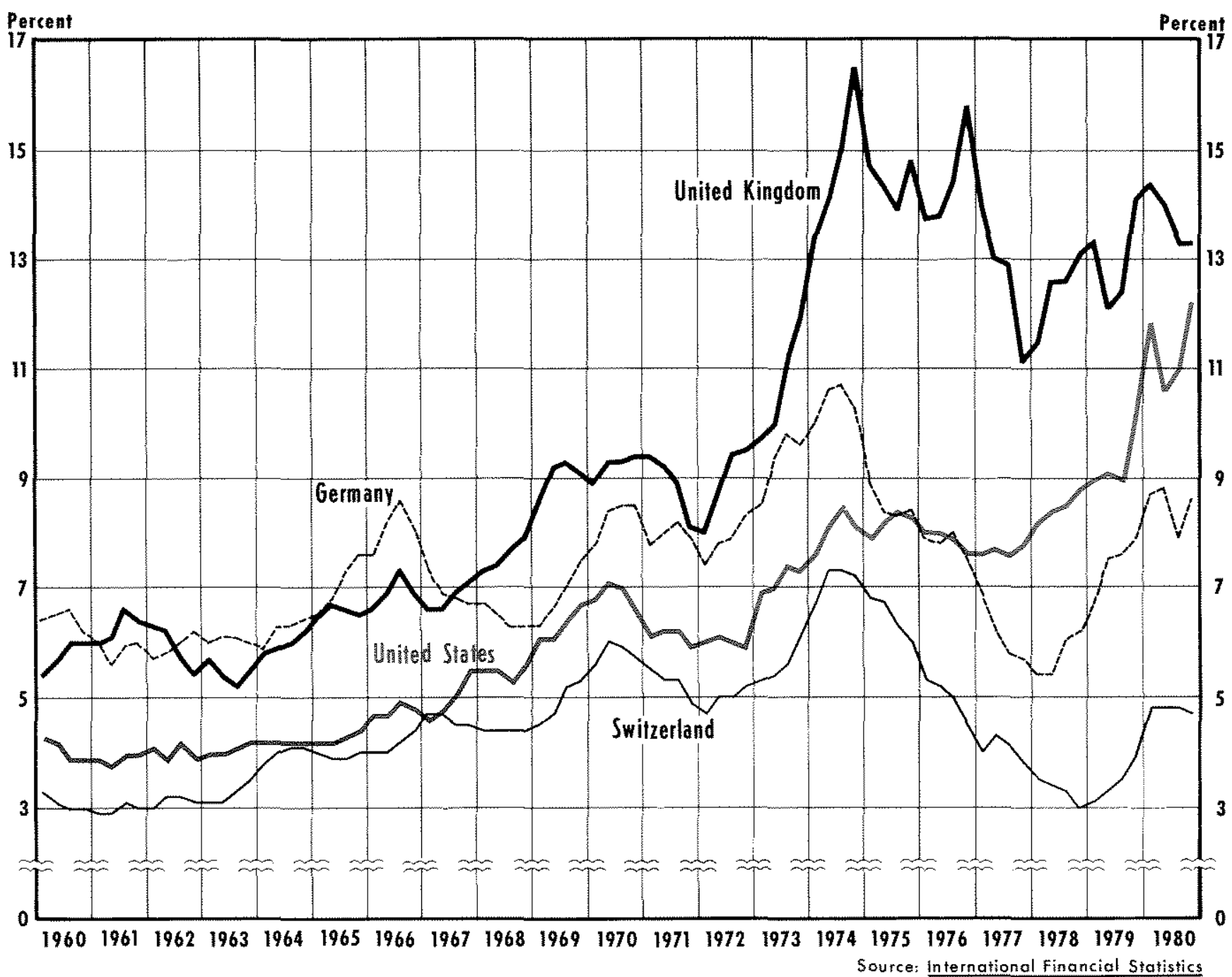

time trend of the quarter-to-quarter ammual rate of money growth, and (c) a linear time trend of the quarter-to-quarter annual rate of price growth for the United States, the United Kingdom, Germany and Switzerland over the last two decades. ${ }^{7}$ Contrary to popular opinion, it appears from the charts that money growth in the United States has been rela-

${ }^{7}$ The monetary aggregate used is M1 for Gemany, Switzerland and the United Kingdom and MIB for the United States. The price measure employed is the GNP defator for Germany, the United Kingdom and the United States. Since the GNP deflator is reported only annually in Switzerland, the consumer price index is used. Except for the United Kingdom, the time period analyzed is $1960-80$. Due to the anavailability of monetary data for the United Kingdom prior to 1963 , the analysis is performed over the period $1963-80$. tively more stable during this period than in any of the other three countries. This observation is confirmed by the calculated measures of dispersion (variability) reported in table $1 .{ }^{8}$ Both the standard deviation and the coefficient of variation of the rate of money growth are smaller for the United States than for any of the other countries. Also, it is not surprising that ontput growth has been less variable

\footnotetext{
${ }^{8}$ The standard deviation - a measure of the dispersion of a variable around its arithmetic mean - is the measure of variability typically used. However, when comparing the variability of two variables with different means, the comparison of standard dewations may be misleading. Consequently, the coefficient of variation - the ratio of the standard deviation to the mean mu is frequently used in this situation. The coefficient of variation measures the dispersion of a variable as a percentage of its mean.
} 


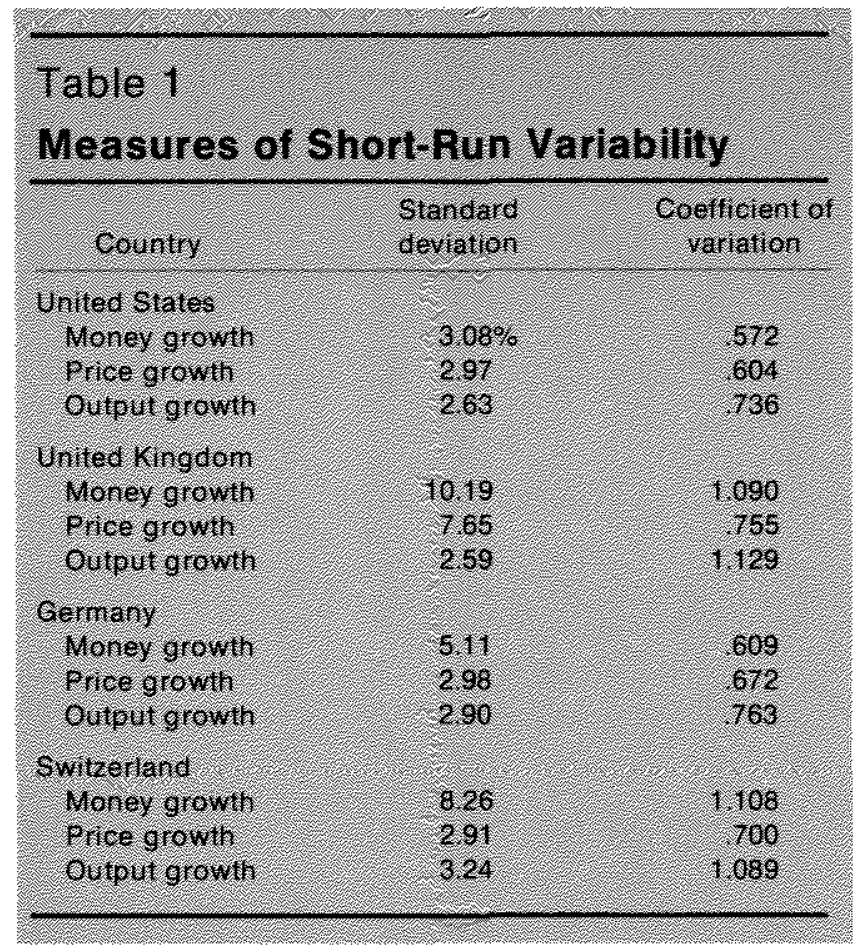

(measured by the coefficient of variation) in the United States; that is, relatively more stable money growth in the United States apparently has led to relatively less fluctuation in output grow th over the last two decades.

An indicator of systematic changes in the rate of money growth over time is necessary to evaluate the performance of monetary authorities in the long run. The estimated linear time trend equations in table 2 provide measures of systematic change in the growth rates of money and prices. In particular, the slope of each equation indicates the change in the rate of growth from one quarter to the next. (For example, the slope of the trend equation for money grow th in the United States is .067 , which means that the annual rate of money growth increased by 6.7 basis points each quarter.) The estimated equations reported in table 2 reveal that over the last 20 years the rates of growth of money in both the United States and the United Kingdom have exhibited positive and statistically significant time trends. As a result, the trend of price growth in each country is also positive and statistically significant. ${ }^{9}$

On the other hand, both the trends of money and price growth in Germany are not significantly dif-

The difference in the slopes of the price trend line and the money trend line can be explained by changes in inflationary expectations and real output growth that affect the demand for money, See the discussion below.

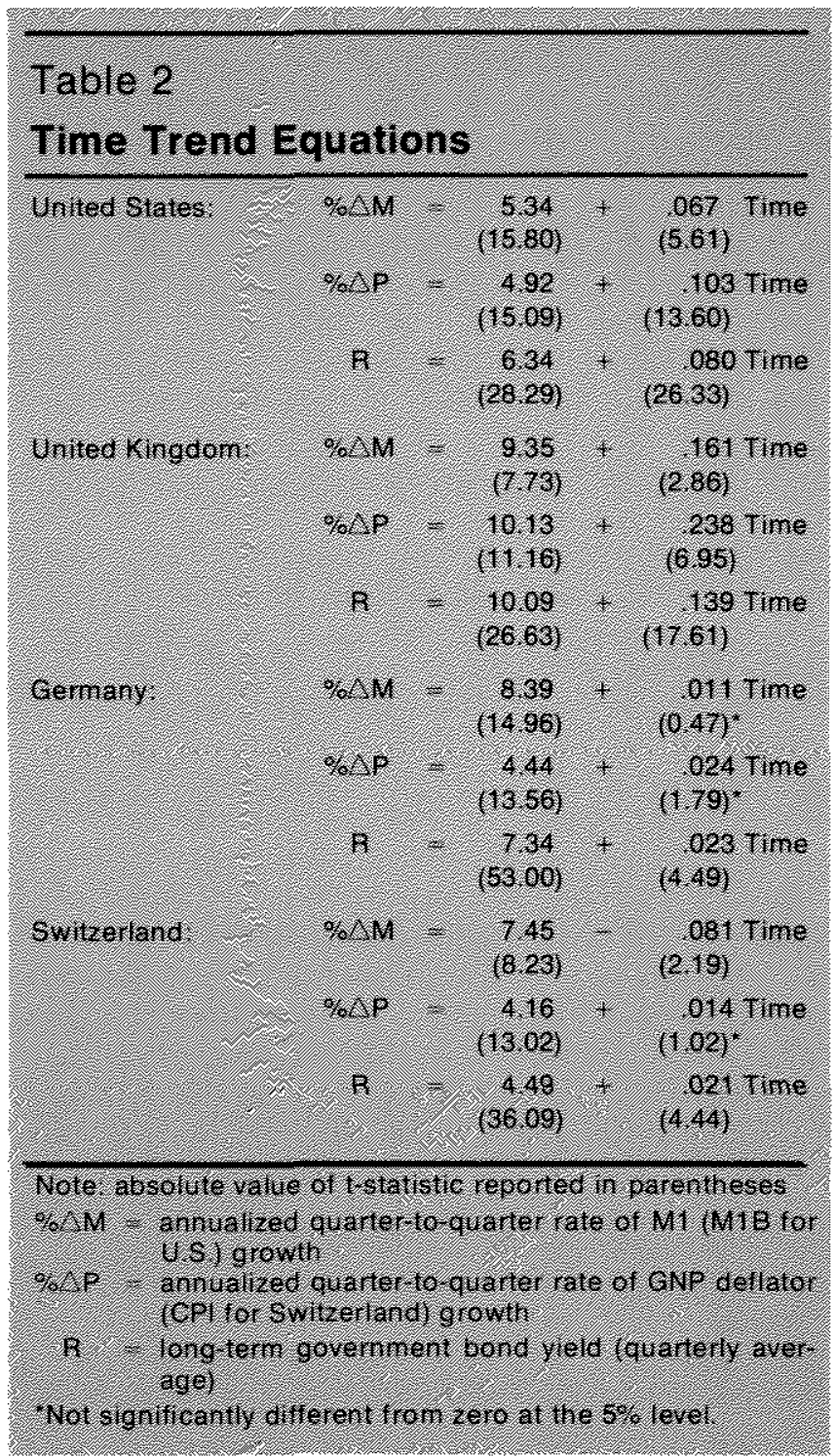

ferent from zero; in Switzerland money growth demonstrates a significant, negative trend, while the trend of price growth is not statistically significant. In other words, accelerating money growth in the United States and the United Kingdom during the past two decades has caused inflation (price level growth) also to accelerate. Alternatively, since the rates of money growth have remained relatively unchanged in both Germany and Switzerland over the past two decades, their rates of inflation have also remained relatively constant during this period.

Another ramification of a rising trend rate of money growth is the inflationary expectation that it generates. Specifically, if the trend rate of money growth is rising (as it is in the United States and the United Kingdom), it is more difficult for market participants to differentiate a temporary deviation 
above the trend from an increase in the trend. Consequently, a period of money growth above the trend rate generates expectations of higher rates of inflation, which result in a decline in the demand for money (other things equal) and create additional inflationary pressures. Alternatively, when the rate of money growth exhibits essentially no trend over time, market participants generally do not confuse temporary deviations from the trend with changes in the trend. As a result, deviations from trend are not as readily translated into inflationary expectations.

The experiences of these four countries support this hypothesis. Since the real interest rate is relatively stable over time, changes in long-term bond yields are a good indicator of changes in inflationary expectations. Long-term bond yields for all four countries each have exhibited a statistically significant, positive time trend; however, those for Germany and Switzerland are notably smaller than those for the United States and the United Kingdom. Using table 2 and chart 2 , one can readily observe that, on average, during the last 20 years, long-term bond yields have risen by only 2 basis points per quarter in Gemany and Switzerland while rising by 8 and 14 basis points in the United States and the United Kingdom, respectively. In other words, while infla- tionary expectations have remained relatively constant in Germany and Switzerland, they have systematically increased in the United States and the United Kingdom over the last two decades. The fact that the price growth trend is more steeply sloped than the money growth trend for both the United States and the United Kingdom also supports this conclusion.

To summarize, short-run money growth has been relatively less variable in the United States than in the United Kingdom, Germany and Switzerland over the last two decades. While stable money growth does provide a good environment for stable real economic growth, it is neither necessary nor sufficient to stabilize prices. The key to price stability is to prevent money growth from accelerating over the long run. Germany and Switzerland have not permitted money growth to accelerate during the last 20 years; as a result, the rates of inflation and inflationary expectations in these countries have remained relatively unchanged. On the other hand, the United States and the United Kingdom have allowed their rates of money growth to accelerate. Consequently, the rate of inflation and inflationary expectations in each country have also increased.

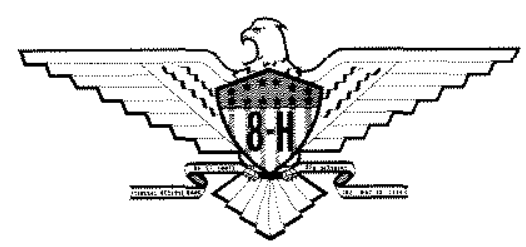

